Article

\title{
Urban Transformations and Complex Values: Insights From Beirut
}

\author{
Elisabetta Pietrostefani ${ }^{1,2}$ \\ ${ }^{1}$ Department of Geography and Environment, London School of Economics and Political Science, UK; \\ e.pietrostefani@Ise.ac.uk \\ 2 Institute for Global Prosperity, University College London, UK
}

Submitted: 30 August 2021 | Accepted: 13 October 2021 | Published: 23 February 2022

\begin{abstract}
Through an urban renewal process driven by a well-resourced Lebanese diaspora and foreign investment, Beirut has undergone conspicuous morphological densification, characterised by parcel aggregation and exploitation of building height. Planning agencies have contributed to these transformations, deliberately involved in the production of illegality, and contributing to unplanned urban development. Although recent literature has substantially furthered our understanding of deregulated planning in Beirut, little is known of the preferences of residents with regards to the urban development process. This article sheds light on how morphological densification affects the complex values attached by residents to their urban environments using a novel data set and mixed-methods approach. It explores how dramatic urban restructuring affects resident values of architectural amenities and neighbourhood belonging. Findings show that although living in areas with different rates of building change does not affect preferences for architectural amenities, it affects resident socio-political activism towards the preservation of their built environment. Residents living in areas with high buildingchange rates had almost $50 \%$ lower odds of being willing to stop new construction near their location of residence because of their lack of confidence in the planning system. Neighbourhood belonging is not significantly affected by construction rates, but substantially increases both with the number of years lived in a neighbourhood and in locations with better building conditions, confirming a role for the built environment.
\end{abstract}

\section{Keywords}

Beirut; deregulated planning; Lebanon; neighbourhood belonging; urban form; willingness to pay

\section{Issue}

This article is part of the issue "Urbanisation, Crisis, and Resilience: The Multiple Dimensions of Urban Transformation in Beirut, Lebanon" edited by Liliane Buccianti-Barakat (Saint Joseph University) and Markus Hesse (University of Luxembourg).

(C) 2022 by the author(s); licensee Cogitatio (Lisbon, Portugal). This article is licensed under a Creative Commons Attribution 4.0 International License (CC BY).

\section{Introduction}

Rapid urban development is a major feature of many less-developed countries. Although we generally think of rapid urbanization taking the form of "informal" or "illegal" settlements in low- and middle-income countries that develop as urban slums (Roy, 2005), motives for urban illegality frequently go beyond the production of housing for low-income urban residents. The state and planning agencies have been deliberately involved in the production of illegality in various Global South contexts (Fawaz, 2017), contributing to deregulated and unplanned urban development which often leads to blatant transformations of urban form.
Beirut is iconic of this phenomenon. Beirut has become a permanent (re)construction site through the urban renewal process driven by a well-resourced Lebanese diaspora and foreign investment since the early 2000s. Urban planning is characterised by neoliberal tendencies and a public-private overlap which has led real-estate profit discourses to hijack notions of urban amenities (Ashkar, 2018; Krijnen, 2018, p. 3). This has been paired with demolition-based urban restructuring for maximum profit. Fawaz (2017, p. 94) highlights the prevalence of the practice of issuing "exceptions" or temporary suspensions of the law in the daily practices of public planning agencies as they manage the production of Beirut's built environment. 
Over the past few decades, many neighbourhoods in Beirut have thus undergone striking alterations, resulting in dramatic changes to the city's landscape, housing stock, and people-space relations (Gebara et al., 2016). The deregulated planning framework has in many cases led to the deterioration of urban environments and to social-cultural instabilities. Although much research has furthered our understanding of deregulated planning in Beirut (Bou Akar, 2018, p. 96; Fawaz, 2017; Krijnen \& Fawaz, 2010, p. 120), little is known of the preferences and responses of local residents in relation to the urban development process.

This article is based on Chapter 4 of my PhD dissertation (Pietrostefani, 2019a). It contributes to ongoing research into strategies to protect and enhance Beirut's social and architectural diversity by exposing, as far as that is possible, residents' complex and multiple values in this regard. Specifically, this article investigates the relationship between construction rates, as indicators of rapid urban transformation, and resident value of architectural amenities and neighbourhood belonging (NB). The study first explores satisfaction with these amenities and examines whether they vary across socioeconomic characteristics. The article then uses stated preference to assess indicative values, and asks: In a context of continual construction with no public consultation, are residents still willing to pay to preserve architectural amenities? And given the climate of "exceptions" present in urban planning in Beirut, does lack of confidence in government affect resident willingness to stop unwarranted construction?

This study uses a novel data set and two case-study neighbourhoods as entry points to examine the relationship between building change (BC) and resident value of architectural amenities and NB. It focuses on the period before the start of the Lebanese financial crisis in 2019 and the 4th of August 2020 Beirut's blast, illustrating residents' responses to urban transformations just before the country's multiple crises. Ras Beirut and Mar Mikhael were selected as case studies as the former has undergone substantial change in urban form over the last few decades, while the latter had only recently seen changes to its urban fabric at the time of the study. These neighbourhoods were also chosen because both areas present multiple cases of urban illegality linked to the production of housing for profit (Fawaz et al., 2018; Khechen, 2018).

The study uses a mixed-methods strategy of qualitative and quantitative approaches to obtain a comprehensive appreciation of the complex relationship between changing urban form and the values residents attach to their urban environments (Greene, 2007). Three modes of analysis were used: survey-based stated preference techniques, descriptive statistics, and textual analysis of discursive survey elements. Survey-based stated preference techniques ask individuals to choose between response options or place a monetary value on a good presented in a hypothetical scenario (for comprehensive reviews, see Alberini \& Kahn, 2006; Bateman et al., 2002).
While descriptive statistics and contingent valuation (CV) are used to identify underlining patterns of resident preferences according to the $B C$ rates of their location of residence. Open-ended survey responses and interviews allow for a better understanding of the reasons behind resident preferences.

CV has been widely used to elicit citizens' preferences and their willingness to preserve architectural amenities (Alberini et al., 2003; Provins et al., 2008), including in less-developed countries where the quality of the urban environment has been increasingly recognised as a determinant of quality of life (Whittington, 2010). A common aspect of CV studies in these contexts, however, is the occurrence of protest responses, which are defined as cases where respondents reject some aspect of the contingent market rather than reveal their true preferences, jeopardizing the validity of the willingness to pay (WTP) estimates (Calia \& Strazzera, 2001; Szabó, 2011). One possible reason for protest responses is respondents' distrust of authorities, or in this case, of planning agencies responsible for changes in the urban environment (Oh \& Hong, 2012). Given the caveats of this methodology, this article adopts WTP as a proxy for residents' intent to stop excessive building practices. Despite its limitations, I consider it a valuable exercise to identify the burden of responsibility individuals in Lebanon may be prepared to incur given the lack of good urban governance (Harb, 2000). Moreover, this article accounts for the limitations of the Lebanese context by analysing motives for lack of WTP through textual analysis and accounts for mistrust in governance through the inclusion of a confidence in government indicator in the WTP regressions.

The article proceeds as follows. Section 2 discusses neoliberal planning in the Lebanese context and explores how changes in urban form can affect values attached to architectural amenities and NB. Section 3 introduces the data and discusses the mixed-methods approach. Section 4 presents findings on overall perceptions of BC, while Section 5 presents the different relationships between $B C$ and the value residents attach to architectural amenities and NB. In Section 6 I discuss the WTP results, revealing a stable negative relationship between WTP to stop new buildings and the rate of BC. Section 7 sets out the conclusions.

\section{A Permanent Construction Site}

\subsection{Is Planning a Political Decision or a Technical Activity?}

Neoliberal tendencies in Beirut facilitate the circulation of capital to the real-estate sector and foster intensive construction practices (Fawaz, 2017; Krijnen, 2018). Article 16 of the Lebanese Construction Law and its 2004 revision enlarged permissible building and resulted in land developers benefiting from exemptions to the total coefficient of exploitation (Ashkar, 2011). This instigated 
further height exploitation, best viewed in terms of financial profit, as higher floors generate more income than lower ones, with the price of apartments in Beirut typically increasing by at least US\$100 per square metre per floor (Ashkar, 2011). Such projects have transformed both the skyline and the social make-up of Beirut, catering to wealthy Lebanese expatriates and other nationals, rather than the city's long-term dwellers.

Moreover, the prevalence of bad governance processes (Harb, 2000), unplanned neighbourhoods (Bou Akar, 2018, p. 6), and the issuance of temporary suspensions of the law to bolster profitable development even further are common practice. These are examples of the rise of state-led informal planning practices happening in many Global South cities (Roy, 2005). Fawaz (2017) argues that "exceptions" constitute one of Beirut's principal planning strategies, originating in clear continuities between the realms of the legal and the illegal, given the entanglement of the political elite and the real-estate industry. In this context, society does not "collectively decid[e] what urban change should look like," as argued by Rydin (2013, p. 12), but quite the opposite. The climate of "exceptions" reveals a struggle over the right to the city.

It is not surprising that these dynamics have led to significant morphological densification in the city, captured by increasing compact urban land cover, street connectivity, and a high building footprint to parcel size ratio (Neuman, 2005). This can also be referred to as the densification of built form: a measure of the intensity of development in relation to available ground-level open space. Beirut's case is characterised by parcel aggregation and exploitation of building height (Khechen, 2018).

Morphological densification has been paralleled by changes in population demographics and socioeconomic backgrounds as a result of internal displacement trends, and the influx of displaced individuals and families following the Syrian crisis. Many displaced people reside in expensive middle-income neighbourhoods because of close access to services and jobs, inserting themselves as best they can, often in informal or un-serviced housing units within these areas, such as this article's case studies, i.e., Ras Beirut and Mar Mikhael (Pietrostefani, 2019b). Although this article will not be focusing on the effects of population change on local neighbourhoods, it will be accounting for it in its analysis, given its impact on this context.

\subsection{Resident Value}

In considering whether morphological change affects how residents value their urban environments, this article focuses on the value residents attach to architectural amenities and feelings of NB. With this double focus, I address both physical and immaterial amenities, as morphological change may influence both objective (visual, aesthetic) and subjective (social, symbolic) dimensions of neighbourhood satisfaction (Young et al., 2004).
Buildings of architectural value have been recognised as land-based public goods in both urban planning, urban economics, and environmental psychology (Ahlfeldt \& Holman, 2018; Brander \& Koetse, 2011; Stamps \& Nasar, 1997). Studies confirm a demand for well-designed buildings and heritage buildings. The value attached to buildings is particularly relevant in Beirut, given both the urban landscape's extensive transformations and the associations attached to architectural styles and types of buildings. As discussed in Section 2.1, high-rise buildings manifest connotations of wealth. Urban heritage buildings and older building stock, although valued by practitioners, academics, and non-governmental agencies (Davie, 2004), are often disregarded by much of the Lebanese population, as illustrated by interviewees, even though these buildings largely represent the remaining part of the city's affordable housing stock (Fawaz et al., 2018).

Examining the meaningful relationships that people have with place(s) has been of academic interest for decades. Urban change has contributed to reshaping communities and altering the cohesion of societies. The neighbourhood is a central element in both environmental psychology and social geography in understanding people's sense of attachment to places, defined as meaningful locations (Lewicka, 2011). NB can represent an emotional bond to a place and is usually seen as positive as it can influence local social networks and engagements associated with well-being and community identity (Finney \& Jivraj, 2013). Neighbourhood relationships and senses of belonging are not universal, however, and some residents will always be excluded. This article contributes to the literature on the relationship between physical urban form and NB (Logan \& Molotch, 2007) while accounting for population change given its prevalence to the context. Recent studies suggest that the type of local population change matters in relation to feelings of NB and that the impact of population change on belonging may be experienced differently by different ethnic groups (Finney \& Jivraj, 2013).

\section{Data and Methodology}

\subsection{Measuring Building Change}

Until recently, only a limited number of records documenting construction activities in Beirut in the last 20 years were available. To investigate the relationship between changing urban form and the value residents attach to their urban environments, I exploit a recent data set on construction permits between 2000 and 2013 (Gebara et al., 2016). Building permits reflect the intentions of financiers to invest and of builders to launch projects. The data was verified and updated until 2017 for the neighbourhoods of Ras Beirut and Mar Mikhael. Construction permit rates are adopted as an indicator of morphological densification. The data was instrumental in the site selection as it allowed the 
identification of areas which have experienced different rates of construction.

The city of Beirut was divided in a fishnet grid of $200 \mathrm{~m}$ by $200 \mathrm{~m}$ square cells, as illustrated in Figure 1. The cells were then limited to the squares overlapping the areas of Ras Beirut and Mar Mikhael, which were selected for their data availability, as previous geolocalised surveys were run in 2009 (Ras Beirut; Kaddour et al., 2014) and 2011 (Mar Mikhael; Buccianti-Barakat et al., 2015), giving me access to indicative measures of population change for both areas. The building permit data was used to construct a simple index of building change $\mathrm{BC}_{c}$ as follows:

$$
\mathrm{BC}_{c}=\frac{\sum_{b=1}^{n} \mathrm{BUP}_{c b}}{\text { area }_{c}}
$$

BUP $_{b}$ is the sum of built-up areas $b$ of all new developments within each square $c$, and area ${ }_{c}$ is the area of each square $c\left(0.04 \mathrm{~km}^{2}\right)$. Once the $\mathrm{BC}$ ratio had been calculated, the squares were divided into quartiles, from areas of high BC to areas of low BC. In Figure 1, red areas display high rates of $B C$ (more than $13 \%$ of the area of a given square), yellow areas display medium rates of $\mathrm{BC}$ (7-13\%), light green areas display low rates (5-7\%), and dark green areas display almost no change to the urban fabric $(<5 \%)$.

Ras Beirut presents higher BC rates than Mar Mikhael. The main reason is that Mar Mikhael only became a prime location since the 2000s (MEDNETA, 2015) whereas Ras Beirut has been one of Beirut's most commercial neighbourhoods for many years (Kaddour et al., 2014; Khechen, 2018). The better the location in terms of historical reputation and open views (including sites with high elevation), the larger the built-up area of new projects (Gebara et al., 2016). Given its different history, Mar Mikhael has managed to retain a significant proportion of buildings from the 1950 s despite recent constructions. A considerable number of new projects in both these prime locations, however, were given exceptional building permits, allowing their developers to bypass zoning regulations and exceed permissible total coefficients of exploitation (krijnen \& Fawaz, 2010). Eighty-three per cent of authorised construction projects were planned on constructed parcels of land as of the 2004 law in Ras Beirut, and $87 \%$ in Mar Mikhael (Gebara et al., 2016).

\subsection{Mixed Methods: Survey and Interview Data}

This article uses a mixed-methods strategy. It draws on descriptive regression analysis of a household survey to identify patterns and detect the relative magnitudes of resident preferences for the urban amenities considered. Both ordinal and binary logistic models are used. Weights compensate for unequal sampling rates and for the possibility that certain populations may not have been included in the sampling frame. Given the climate of deregulated planning, I attempt to account for a possible bias in stated WTP considering mistrust in governmental institutions and developers by controlling for confidence in local government. Table 1 presents the main variables used. In the absence of panel or other cross-section comparisons to control for endogeneity, qualitative data is used to complement, validate, and develop the results obtained from that analysis (Greene, 2007; Lieberman, 2005). Exploration of open-ended survey responses and interviews allowed a better understanding of the reasons behind residents' preferences.

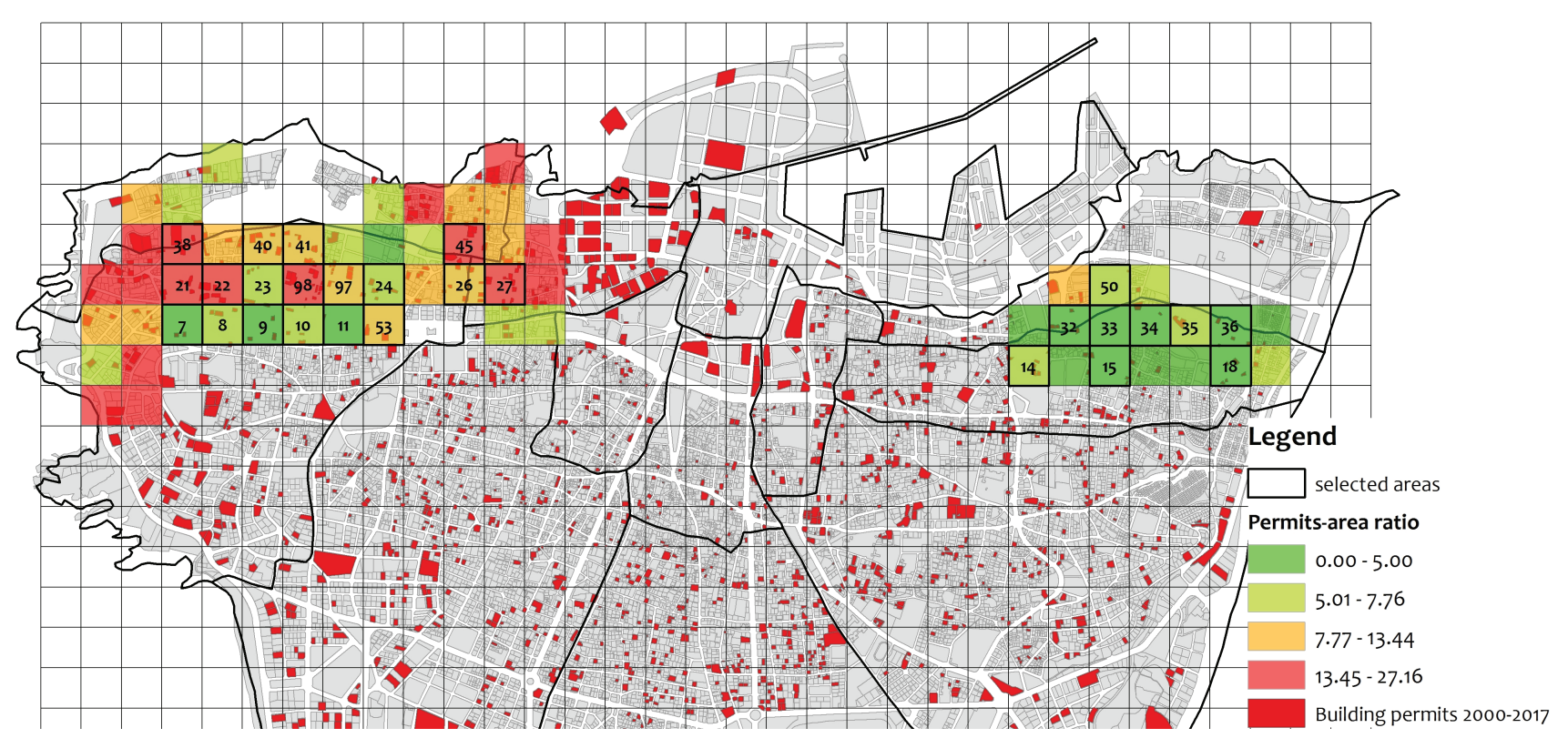

Figure 1. Sampling grid. 
Table 1. Summary statistics.

\begin{tabular}{|c|c|c|c|c|}
\hline & Mean & SD & Min & Max \\
\hline $\mathrm{BC}$ ratio (quartile) & 2.44 & 1.092 & 1 & 4 \\
\hline WTP to stop development (image) & 2.97 & 2.35 & 1 & 9 \\
\hline$N B^{h}$ & 3.49 & 0.91 & 1 & 5.125 \\
\hline Confidence in government ${ }^{i}$ & 2.76 & 0.77 & 1 & 5 \\
\hline Age $^{a}$ & 3.28 & 1.25 & 1 & 5 \\
\hline Nationality ${ }^{b}$ & 1.31 & 0.60 & 1 & 3 \\
\hline Gender $^{c}$ & 1.50 & 0.50 & 1 & 2 \\
\hline Education $^{d}$ & 3.29 & 0.88 & 1 & 4 \\
\hline Years lived in neighbourhood & 21.21 & 20.00 & 0 & 78 \\
\hline Income ${ }^{e}$ & 3.76 & 1.94 & 1 & 8 \\
\hline Ownership or rent ${ }^{f}$ & 2.14 & 0.99 & 1 & 5 \\
\hline Religion $\mathrm{g}$ & 3.75 & 3.96 & 1 & 11 \\
\hline
\end{tabular}

Notes: ${ }^{a}$ Age brackets: $1 .<21 ; 2.22-34 ; 3.35-49 ; 4.50-64 ; 5 .>65 .{ }^{b}$ Nationalities: 1. Lebanese, 2. Syrian or Palestinian, 3. Other. ${ }^{c}$ Gender: 1. Man, 2. Woman. ${ }^{d}$ Education brackets: 1 . None, 2. Elementary, 3. Secondary, 4. University. ${ }^{\mathrm{e}}$ Income brackets: $1 . \$ 450$ (minimum wage), 2. $\$ 450-1,600,3$. $\$ 1,601-3,000,4 . \$ 3,001-5,000,5 . \$ 5,001-8,000,6 . \$ 8,001-12,000,7 . \$ 12,001-16,000,8 .>\$ 16,001 .{ }^{f}$ House tenure: 1. Old ownership, 2. Old rent, 3. New rent, 4. No rent. ${ }^{\mathrm{g}}$ Religion brackets: 1 . Muslim, 2. Christian, 3. Druze, 4. Atheist, 5. Refused to answer. ${ }^{\mathrm{h}}$ Average of NB variables (belonging, friendship and associations, advice, borrowing, remaining a resident, talking to people, helping neighbours, trust in neighbours, knowing neighbours by name). ${ }^{i}$ Average of confidence in government variables (confidence in Muhtar, municipality, political parties, parliament, religious bodies, media, NGOs, police).

\section{Contradictions of Morphological Change}

The survey first asked respondents to briefly describe the physical environment of their street, without being biased by detailed questions. While Mar Mikhael was valued for the quality of its environment as a "village-like" "old neighbourhood with heritage buildings," it was also described as "dirty," "unkempt," and "needing renovation." Ras Beirut was considered a "mixed" neighbourhood, which had become "cleaner after renovations," despite its lack of "open spaces."

This excerpt of quotes instantly underlines the complex nature of the connotations associated with changes in urban form. Because of their neglected state, areas with historical or well-designed urban fabric are not necessarily valued more highly than areas reconstructed with large numbers of high-rise structures. Location was the core theme that emerged when respondents were asked what they most valued about their neighbourhood, highlighting the importance of access to services and retail amenities, and confirming the similarity of these neighbourhoods in this respect. Community cohesion (or neighbourliness) was also highlighted as a key aspect valued in both neighbourhoods.

Respondents were then asked about their satisfaction with the physical aspects of their urban environments in more detail. Figure 2 shows how residents in areas with high $\mathrm{BC}$ rates were on average more satisfied with the physical transformations of their neighbourhoods. Moreover, more residents in high BC rate areas considered the overall condition of the buildings in their neighbourhood "excellent" and even found the condition of some older buildings "excellent." Interviews with local NGOs suggested heritage building restoration had recently been more frequent in Ras Beirut, both for commercial and non-profit uses. Higher BC rates therefore have a positive relationship with higher satisfaction of local urban environments. And yet, finding newly redeveloped places more attractive does not necessarily imply a lack of resident interest in preserving more traditional urban environments or stopping excessive building.

In fact, contradictions in the survey responses became apparent while plotting different variable relationships, in many ways reflecting the contradictions of Beirut's construction patterns and underlining the importance of a mixed-methods approach. For instance, while $60 \%$ of residents considered new constructions to be attractive, when asked directly if they preferred Beirut's traditional urban stock or new high-rise buildings, $75 \%$ preferred traditional building stock. Other variables influencing building-type preferences are education and income, number of years lived in a neighbourhood, and type of building lived in as a child, and are not reported here for brevity.

The morphological evolution of a city is problematic because buildings are almost necessarily related to socioeconomic status (Ragette, 1980). This is especially relevant in contexts where state policies and market forces converge to make profit-driven real estate a pillar of the neoliberal economy, while offering no housing, social, or economic policies to redress its gentrifying 
Satisfied Physical Transformation N

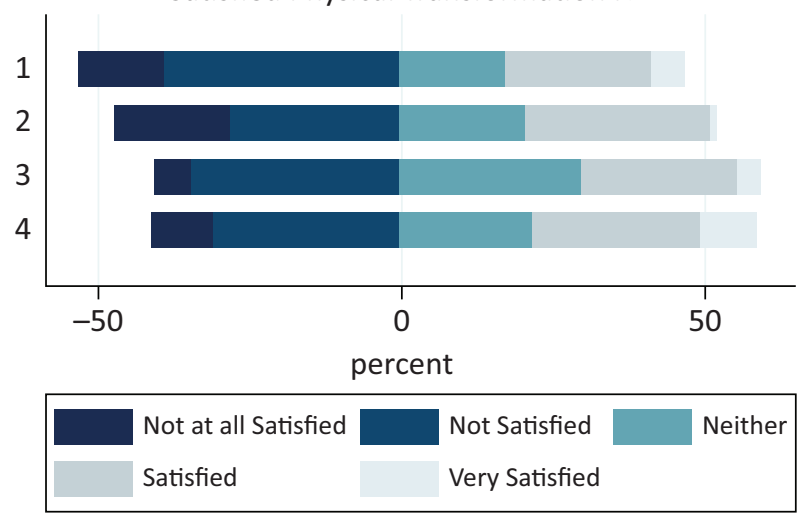

Old Building Condition Local N

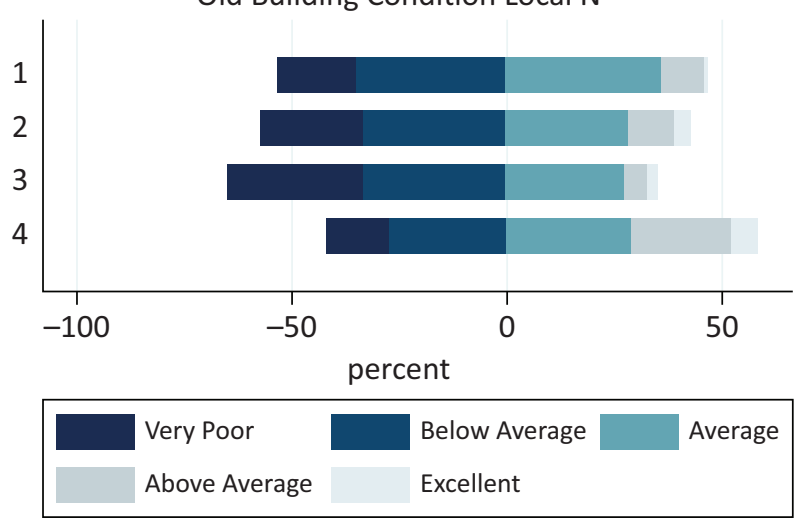

Building Condition Local N

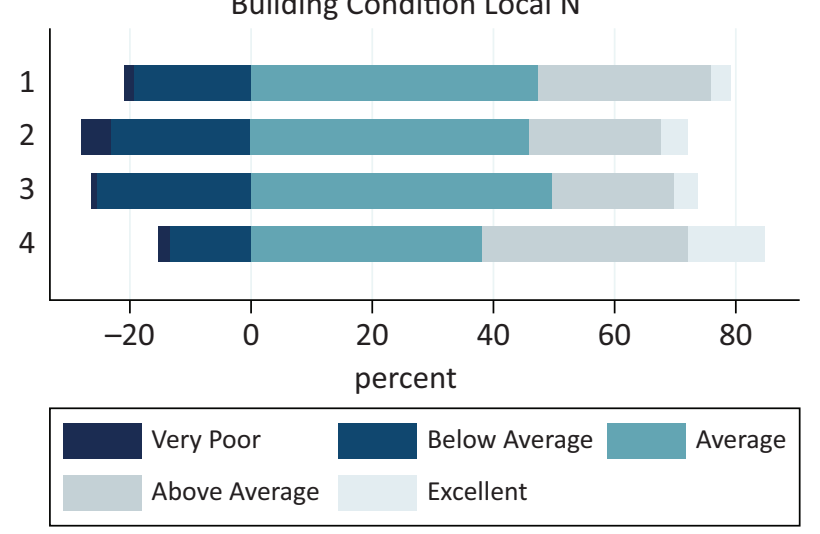

Attractive New Constructions

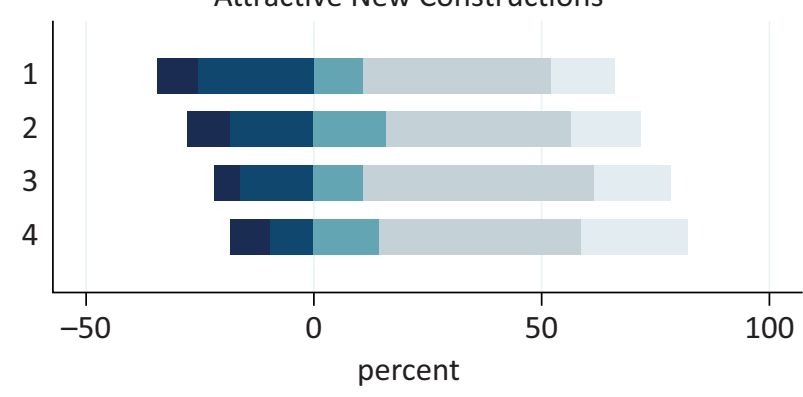

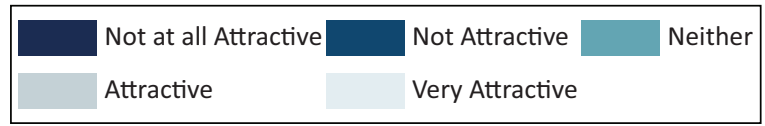

Figure 2. Building conditions. Note: 1-4 indicate the quartiles of $B C, 1$ being the least change and 4 being the most change. $\mathrm{N}$ stands for neighbourhood.

effects. Residents associate BC not only with the evolution of urban physical form but also with changes in local socioeconomic make-up. Interviewees confirmed that the socioeconomic status of buildings is typically well-understood by urban citizens as new constructions are usually preceded by evictions and pressured displacement (Bekdache, 2015). Respondents in Mar Mikhael living in pre-1990 building stock commented that, if a tall building was being built next to them, it would probably result in their forced displacement next.

These relationships are important in explaining the background to the WTP analysis. On the one hand, the responses suggest that the deregulated planning practices "making Beirut for its buildings" are in many ways accepted by society, in contradiction to one of Jacobs' (1961) famous arguments that plans for a city should be made not for its buildings but for its people. In some ways, preferences can therefore be seen to be in opposition to widespread discourses in sustainable urban growth. On the other hand, residents in areas with low $B C$ rates are dissatisfied with the changes occurring in their neighbourhoods.

\section{Values in a Changing Urban Environment}

The aspect of "neighbourliness" highlighted in the initial open answers of the survey confirmed the importance of addressing both physical and subjective neighbourhood values in considering the possible effects of morphological change (Young et al., 2004).

\subsection{Architectural Amenities}

Both urban heritage and well-designed modern buildings were generally valued by respondents, with $85 \%$ of respondents strongly agreeing with the importance of preserving both types of buildings. Residents were more likely to sign a petition opposing a major change in their neighbourhood if they lived in areas with lower BC rates. Of the $10 \%$ of respondents who had signed a petition in the last year, $65 \%$ lived in areas that had undergone low or almost no change to their urban fabric. Findings also show that the probability of signing a petition increased with age and that Lebanese were more likely to sign a petition than non-Lebanese nationals. Higher levels of education also increased the probability of signing a petition. 
Interviews with local community-based organizations in Mar Mikhael confirmed that they had received some support from residents publicly opposing recently confirmed construction projects, even though "most residents have lost hope that socio-political activism will make any difference." The research thus suggests a discordance between values residents attach to architectural amenities and actual action towards their preservation. These same residents living in areas with low BC rates did not believe legislation to be the best mechanism with which to protect the integrity of urban environments. Interviewees explained that NGOs and other activists have pushed towards legislative solutions to demolition-based constructions with few successes. The Transfer of Development Rights Law (12/10/2017) was a small achievement, intended to allow owners to retain their low-rise buildings while letting them benefit from the development value of their land by enabling them to sell their "air space," thereby gaining revenue to renovate their building. Although this law was passed through parliament, the government has yet to ratify it.

\subsection{Neighbourhood Belonging}

When considering local neighbourhood ties and actions, the baseline regression presented in Table 2 reveals that location, at least in the case of these two neighbourhoods, is insignificant as other relevant confounders are added to the analysis (Wald test $=1.70 ; \mathrm{P}>0.05$ ). The data is analysed by neighbourhood because respondents are being asked about their neighbourhood as a whole. Age is an important determinant of NB (Wald test $=5.24 ; \mathrm{P}<0.01$ ), where the older the resident the more likely the feeling of NB. Nationality does not significantly influence feelings of NB. This tendency is in fact driven by the number of years lived in a place (Wald test $=33.91 ; \mathrm{P}<0.001$ ). Perceived good quality of building conditions also increases the likelihood of strong NB, indicating a key role for the built environment (Wald test $=10.82 ; \mathrm{P}<0.001$ ).

The likelihood of having signed a petition to oppose a major change to the local urban environment does not significantly affect NB (Table 2). There is therefore no evidence that neighbourhood-based social relations are influenced by residents' reactions to changing forms of urban governance and policy (Johnstone \& Whitehead, 2004). This might be a result of the feeble successes that socio-political activism has had in these contexts. Although the "concept of neighbourhood has salience when acted upon...for political or social purposes" (Martin, 2003, p. 380), this is usually reinforced with obtaining desired outcomes, which has not been the case in this case study. The change in percentage of the non-Lebanese population (2009-2018), largely driven by the influx of displaced Syrians, highlighted by many respondents as one of the main sources of change in both neighbourhoods, negatively influences
NB but is not significant. This suggests that despite Lebanese discontent with the Syrian influx, as noted by $65 \%$ of Lebanese respondents, the "hidden" quality of Syrian neighbours (Pietrostefani, 2019b) does not significantly lower the odds of feeling strong NB. Qualitative commentaries suggested that this lack of significance may be driven by Ras Beirut, whose long-term residents although wary of newcomers live in a historically demographically mixed area. Indeed, a focus on the Mar Mikhael subset suggests a negative and significant relationship in this neighbourhood, in line with research that finds that the arrival of "racialised others" can be perceived as a disruption (Watt, 2010, p. 154).

\section{Are Residents Still Willing to Stop Unwarranted Building?}

The WTP section in the survey was introduced with a hypothetical scenario. Respondents were asked to imagine they could decide whether a building would be demolished, and a tall new building constructed to replace it as visualised in Figure 3. They were then asked if they would be willing to pay the developer to prevent this change and how much they would be ready to pay every month for a year.

Although CV exercises such as this one have gained increasing acceptance in academic and policy-making circles (Carson et al., 2001), WTP has been shown to be particularly low in less-developed countries both in absolute terms and as a percentage of income (Whittington, 2010). Indeed, considering the low trust in institutions and third-party non-sectarian ties in Lebanon (Bou Akar, 2018), the concept of WTP in a hypothetical scenario was often understood with difficulty, the principal caveat being that paying for a public good is detached from Lebanese reality. Various strategies were therefore adopted in the question design and survey implementation to improve respondents' understanding of the exercise.

This section of the survey focused on one simple attribute-new buildings - as the urban reality of Beirut with its multi-faceted changes makes it difficult to present more complex situations. The specific time frame and monthly instalment scenario were chosen to simplify the conception of the payment method and to give assurance that this payment would not be indefinite. Surveyors were trained to explain that in the hypothetical set-up respondents' monetary contributions would be allocated to stop new building construction, and pictures as in Figure 3 were presented as visual aids. Twenty-four per cent of respondents commented that a new building had been constructed very close to their residence at some point in their life, and although giving residents decision power was almost unheard of, $62 \%$ of respondents accepted the conceptual framework of the exercise. Respondents who rejected the framework were recorded to later account for this in the regression analysis. Moreover, given the caveats of WTP, I interpret 
Table 2. Results of NB logit analysis.

\begin{tabular}{|c|c|c|c|c|c|c|c|c|c|c|c|c|c|c|}
\hline \multirow[b]{2}{*}{ NB } & \multicolumn{7}{|c|}{ Model I: Ordinal Logistic Regression, $\mathrm{OR}^{\mathrm{a}}$} & \multicolumn{7}{|c|}{ Model II: Binary Logistic Regression, OR ${ }^{\text {b }}$} \\
\hline & (1) & (2) & (3) & (4) & (5) & (6) & (7) & (8) & (9) & (10) & (11) & (12) & (13) & (14) \\
\hline Ras Beirut $^{c}$ & $\begin{array}{l}0.670^{* * *} \\
(0.0793)\end{array}$ & $\begin{array}{l}0.795 * \\
(0.0968)\end{array}$ & $\begin{array}{l}0.794^{*} \\
(0.0968)\end{array}$ & $\begin{array}{c}0.893 \\
(0.111)\end{array}$ & $\begin{array}{c}0.860 \\
(0.108)\end{array}$ & $\begin{array}{c}0.855 \\
(0.109)\end{array}$ & $\begin{array}{c}0.866 \\
(0.110)\end{array}$ & $\begin{array}{l}0.643^{* * *} \\
(0.0870)\end{array}$ & $\begin{array}{c}0.774^{*} \\
(0.112)\end{array}$ & $\begin{array}{c}0.771^{*} \\
(0.111)\end{array}$ & $\begin{array}{c}0.863 \\
(0.128)\end{array}$ & $\begin{array}{c}0.821 \\
(0.124)\end{array}$ & $\begin{array}{c}0.802 \\
(0.123)\end{array}$ & $\begin{array}{c}0.811 \\
(0.124)\end{array}$ \\
\hline Age & & $\begin{array}{l}1.436 * * * \\
(0.0728)\end{array}$ & $\begin{array}{l}1.433^{* * *} \\
(0.0726)\end{array}$ & $\begin{array}{c}1.129 * * \\
(0.0683)\end{array}$ & $\begin{array}{c}1.132 * * \\
(0.0687)\end{array}$ & $\begin{array}{c}1.133^{* *} \\
(0.0687)\end{array}$ & $\begin{array}{c}1.134^{* *} \\
(0.0689)\end{array}$ & & $\begin{array}{l}1.475^{* * *} \\
(0.0908)\end{array}$ & $\begin{array}{l}1.479 * * * \\
(0.0914)\end{array}$ & $\begin{array}{c}1.172 * * \\
(0.0863)\end{array}$ & $\begin{array}{c}1.164^{* *} \\
(0.0861)\end{array}$ & $\begin{array}{c}1.167^{* *} \\
(0.0863)\end{array}$ & $\begin{array}{c}1.163 * * \\
(0.0860)\end{array}$ \\
\hline 2. Syrian & & $\begin{array}{c}0.849 \\
(0.151)\end{array}$ & $\begin{array}{c}0.880 \\
(0.158)\end{array}$ & $\begin{array}{c}1.205 \\
(0.225)\end{array}$ & $\begin{array}{c}1.134 \\
(0.214)\end{array}$ & $\begin{array}{c}1.132 \\
(0.214)\end{array}$ & $\begin{array}{c}1.140 \\
(0.216)\end{array}$ & & $\begin{array}{c}0.927 \\
(0.198)\end{array}$ & $\begin{array}{c}0.955 \\
(0.206)\end{array}$ & $\begin{array}{c}1.301 \\
(0.296)\end{array}$ & $\begin{array}{c}1.227 \\
(0.283)\end{array}$ & $\begin{array}{c}1.225 \\
(0.283)\end{array}$ & $\begin{array}{c}1.221 \\
(0.282)\end{array}$ \\
\hline 3. Other & & $\begin{array}{l}0.416 * * * \\
(0.0941)\end{array}$ & $\begin{array}{c}0.415^{* * *} \\
(0.0944)\end{array}$ & $\begin{array}{l}0.602^{* *} \\
(0.141)\end{array}$ & $\begin{array}{l}0.571^{* *} \\
(0.135)\end{array}$ & $\begin{array}{l}0.570 * * \\
(0.134)\end{array}$ & $\begin{array}{l}0.574^{* *} \\
(0.135)\end{array}$ & & $\begin{array}{l}0.472^{* *} \\
(0.148)\end{array}$ & $\begin{array}{l}0.471^{* *} \\
(0.148)\end{array}$ & $\begin{array}{c}0.681 \\
(0.222)\end{array}$ & $\begin{array}{c}0.660 \\
(0.216)\end{array}$ & $\begin{array}{c}0.655 \\
(0.214)\end{array}$ & $\begin{array}{c}0.656 \\
(0.215)\end{array}$ \\
\hline 2. Female & & $\begin{array}{c}0.775^{* *} \\
(0.0902)\end{array}$ & $\begin{array}{c}0.784^{* *} \\
(0.0915)\end{array}$ & $\begin{array}{r}0.793 * * \\
(0.0933)\end{array}$ & $\begin{array}{c}0.784^{* *} \\
(0.0926)\end{array}$ & $\begin{array}{c}0.784^{* *} \\
(0.0926)\end{array}$ & $\begin{array}{r}0.782 * * \\
(0.0925)\end{array}$ & & $\begin{array}{c}0.850 \\
(0.119)\end{array}$ & $\begin{array}{c}0.855 \\
(0.119)\end{array}$ & $\begin{array}{c}0.895 \\
(0.128)\end{array}$ & $\begin{array}{c}0.896 \\
(0.129)\end{array}$ & $\begin{array}{c}0.896 \\
(0.130)\end{array}$ & $\begin{array}{c}0.897 \\
(0.130)\end{array}$ \\
\hline Education & & $\begin{array}{l}0.810^{* * *} \\
(0.0592)\end{array}$ & $\begin{array}{c}0.777^{* * *} \\
(0.0598)\end{array}$ & $\begin{array}{c}0.802^{* * *} \\
(0.0631)\end{array}$ & $\begin{array}{c}0.835^{* *} \\
(0.0665)\end{array}$ & $\begin{array}{c}0.835^{* *} \\
(0.0665)\end{array}$ & $\begin{array}{c}0.833^{* *} \\
(0.0665)\end{array}$ & & $\begin{array}{c}0.754^{* * *} \\
(0.0634)\end{array}$ & $\begin{array}{c}0.728^{* * *} \\
(0.0647)\end{array}$ & $\begin{array}{l}0.735 * * * \\
(0.0671)\end{array}$ & $\begin{array}{l}0.758^{* * *} \\
(0.0702)\end{array}$ & $\begin{array}{c}0.760^{* * *} \\
(0.0704)\end{array}$ & $\begin{array}{l}0.761^{* * *} \\
(0.0706)\end{array}$ \\
\hline Income & & & $\begin{array}{l}1.056^{*} \\
(0.0325)\end{array}$ & $\begin{array}{c}1.064^{* *} \\
(0.0330)\end{array}$ & $\begin{array}{c}1.059 * \\
(0.0331)\end{array}$ & $\begin{array}{c}1.060^{*} \\
(0.0333)\end{array}$ & $\begin{array}{l}1.058^{*} \\
(0.0331)\end{array}$ & & & $\begin{array}{l}1.048 \\
(0.0398)\end{array}$ & $\begin{array}{l}1.062 \\
(0.0415)\end{array}$ & $\begin{array}{l}1.060 \\
(0.0420)\end{array}$ & $\begin{array}{l}1.064 \\
(0.0423)\end{array}$ & $\begin{array}{l}1.062 \\
(0.0422)\end{array}$ \\
\hline $\begin{array}{l}\mathrm{N}^{\circ} \text { years } \\
\text { lived }\end{array}$ & & & & $\begin{array}{c}1.030 * * * \\
(0.00417)\end{array}$ & $\begin{array}{c}1.029 * * * \\
(0.00418)\end{array}$ & $\begin{array}{c}1.030 * * * \\
(0.00419)\end{array}$ & $\begin{array}{c}1.029 * * * \\
(0.00418)\end{array}$ & & & & $\begin{array}{c}1.027^{* * *} \\
(0.00477)\end{array}$ & $\begin{array}{c}1.028 * * * \\
(0.00481)\end{array}$ & $\begin{array}{c}1.028 * * * \\
(0.00483)\end{array}$ & $\begin{array}{c}1.028^{* * *} \\
(0.00482)\end{array}$ \\
\hline $\begin{array}{l}\text { Building } \\
\text { cond. }{ }^{d}\end{array}$ & & & & & $\begin{array}{l}1.259 * * * \\
(0.0855)\end{array}$ & $\begin{array}{l}1.259 * * * \\
(0.0855)\end{array}$ & $\begin{array}{l}1.261 * * * \\
(0.0857)\end{array}$ & & & & & $\begin{array}{l}1.313^{* * *} \\
(0.109)\end{array}$ & $\begin{array}{l}1.312^{* * *} \\
(0.109)\end{array}$ & $\begin{array}{l}1.310^{* * *} \\
(0.109)\end{array}$ \\
\hline Petition $^{\mathrm{e}}$ & & & & & & $\begin{array}{c}0.946 \\
(0.186)\end{array}$ & & & & & & & $\begin{array}{c}0.806 \\
(0.191)\end{array}$ & \\
\hline $\begin{array}{l}\Delta \% \\
\text { Non-Leb. }{ }^{f}\end{array}$ & & & & & & & $\begin{array}{c}0.618 \\
(0.237)\end{array}$ & & & & & & & $\begin{array}{c}0.636 \\
(0.215)\end{array}$ \\
\hline Observations & 1,055 & 1,055 & 1,055 & 1,050 & 1,043 & 1,043 & 1,043 & 1,055 & 1,055 & 1,055 & 1,050 & 1,043 & 1,043 & 1,043 \\
\hline Log likelihood & $-1,425$ & $-1,373$ & $-1,372$ & $-1,337$ & $-1,322$ & $-1,322$ & $-1,312$ & -699 & -627 & -626 & -606 & -595 & -595 & -595 \\
\hline LR chi2 & 11.49 & 114.74 & 124.88 & 161.93 & 170.50 & 197.27 & 234.67 & 10.56 & 124.08 & 124.88 & 161.93 & 170.50 & 197.27 & 198.43 \\
\hline Pseudo R2 & 0.07 & 0.09 & 0.09 & 0.12 & 0.13 & 0.14 & 0.20 & 0.07 & 0.09 & 0.09 & 0.12 & 0.13 & 0.15 & 0.18 \\
\hline
\end{tabular}

Notes: Logistic models fitted and interpreted in terms of their coefficients interpreted as odds ratios. If the $O R>1$, then the odds of $Y=1$ increases, and if the $O R<1$, then the odds of $Y=1$ decreases. ${ }^{a}$ Ordinal NB: 1 (low average rate of NB) to 5 (high average rate of NB). ${ }^{b}$ Top quintile of NB: $1=$ top quintile, $0=$ all else. ${ }^{c} 1$. Mar Mikhael, 2 . Ras Beirut. ${ }^{d}$ Building conditions: 1 . Very poor, 2. Below average, 3. Above average, 4 . Excellent. ${ }^{\text {e }}$ Signed a petition to oppose major change dummy. ${ }^{f} \Delta \%$ of non-Lebanese residents per neighbourhood block. ${ }^{*} p<0.05,{ }^{* *} p<0.01,{ }^{* * *} p<0.001$. 

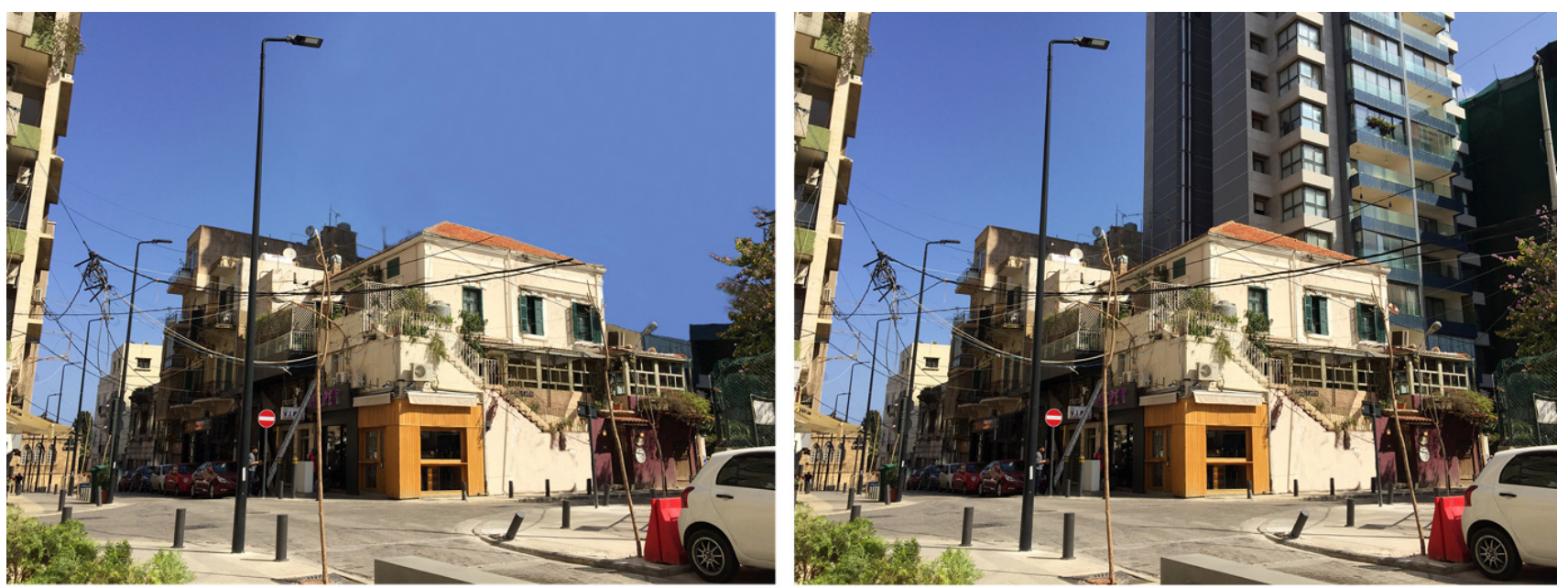

Figure 3. An example of a visualisation of BC: Before and after.

WTP as a proxy for resident willingness to stop unwarranted building. I also compare these results with other related indicators.

Respondents were first asked how much the presented tall building scenario would bother or stress them. A new skyscraper being built bothered and stressed residents considerably less in areas with high $\mathrm{BC}$ rates. Reasons behind this are illustrated in the respondents' comments: "This has already happened in my area, I have no way of stopping this" and "There are already tall buildings blocking my views around me." One respondent even insisted on showing the interviewer how their terrace, which once had a view, was now simply a space between two concrete walls, as the side of a new building had been erected immediately next to the edge of the terrace.

Estimates presented in Table 3 mirror these observations. I find a negative relationship between WTP and BC rates, which is especially pronounced for the last quartile of the $B C$ variable. Residents living in areas with high $B C$ rates have almost $50 \%$ lower odds of being willing to pay to stop new construction near their location of residence. This suggests that there is a desire to stop excessive building practices in areas that maintain low rates of $\mathrm{BC}$, but less in areas that have already undergone a heavy urban transformation. Residents in low BC areas mostly remarked that the renovation they sought did not involve substantial transformation of building form and design but was centred around infrastructural renovation and modernization of existing buildings rather than complete substitution. This is supported by greater percentages of residents having petitioned to object to a major change in their urban environments in areas with low $\mathrm{BC}$ rates. Forty-nine per cent of residents were willing to pay the developer to prevent a new building from rising next to their current residence when asked without a picture illustrating the change, while $51 \%$ were willing to pay when asked with a picture (Figure 3 ). Although this is just a small increase, it signals the significance of visual aids in building environment question design.
Table 3 also shows collateral findings. Older residents are less willing to pay to stop excessive construction. Non-Lebanese residents are less willing to pay to stop new constructions, but this is only weakly significant. Residents with higher education present higher WTP, but education becomes insignificant with the inclusion of income, stressing, as noted in the literature (Alberini et al., 2003), the role of resident disposable income in the economic valuation of public goods. While valuing protection of urban heritage and well-designed architecture has a strong positive relationship with WTP, having signed a petition has a significantly negative relationship with WTP, possibly detecting the "lost hope" of residents who have been active in safeguarding their urban environments. Residents having strong feelings of NB have close to $50 \%$ higher odds of being willing to stop new constructions and, as predicted, confidence in local government has a negative and significant relationship with WTP, underlining resident mistrust of local institutions.

An open-ended question was asked to residents who were not willing to pay, to enquire further about the reasons behind their decision. This question helped reveal genuine zero (WTP $=0$ ) and protest responses comprehensively (Brander \& Koetse, 2011). In line with other literature (Chen \& Hua, 2015), 32\% of respondents said they could not afford to pay due to budget constraints and a notable $38 \%$ of respondents said they "did not trust developers" and that there was "no point in paying as the building would be built anyway." The respondent distrust with developers and planning agencies responsible for changes in their urban environments is clear, marking the number of responses which rejected the contingent market in light of their lack of trust with the planning system (Oh \& Hong, 2012). Nineteen per cent of respondents remarked that the municipality should be responsible for moderating morphological changes, and the monetary responsibility should not fall with residents. Many of these same respondents also remarked that they did not believe the municipality would take action and this is why they would pay. 
Table 3. Results of WTP logit analysis.

\begin{tabular}{|c|c|c|c|c|c|c|c|c|c|c|c|c|c|c|}
\hline \multirow[b]{2}{*}{ WTP } & \multicolumn{7}{|c|}{ Model I: Ordinal Logistic Regression, OR a } & \multicolumn{7}{|c|}{ Model II: Binary Logistic Regression, OR b } \\
\hline & (1) & (2) & (3) & (4) & (5) & (6) & (7) & (8) & (9) & (10) & (11) & (12) & (13) & (14) \\
\hline 2. BC light green & $\begin{array}{c}0.746^{*} \\
(0.120)\end{array}$ & $\begin{array}{l}0.714^{* *} \\
(0.116)\end{array}$ & $\begin{array}{c}0.747^{*} \\
(0.124)\end{array}$ & $\begin{array}{c}0.754^{*} \\
(0.126)\end{array}$ & $\begin{array}{c}0.760 \\
(0.127)\end{array}$ & $\begin{array}{c}0.806 \\
(0.135)\end{array}$ & $\begin{array}{c}0.785 \\
(0.132)\end{array}$ & $\begin{array}{c}0.839 \\
(0.145)\end{array}$ & $\begin{array}{c}0.795 \\
(0.140)\end{array}$ & $\begin{array}{c}0.826 \\
(0.149)\end{array}$ & $\begin{array}{c}0.829 \\
(0.151)\end{array}$ & $\begin{array}{c}0.833 \\
(0.152)\end{array}$ & $\begin{array}{c}0.865 \\
(0.159)\end{array}$ & $\begin{array}{c}0.840 \\
(0.155)\end{array}$ \\
\hline 3. $\mathrm{BC}$ yellow & $\begin{array}{l}0.737^{* *} \\
(0.114)\end{array}$ & $\begin{array}{l}0.673^{* *} \\
(0.106)\end{array}$ & $\begin{array}{l}0.688^{* *} \\
(0.111)\end{array}$ & $\begin{array}{l}0.718^{* *} \\
(0.117)\end{array}$ & $\begin{array}{l}0.713^{* *} \\
(0.116)\end{array}$ & $\begin{array}{c}0.750^{*} \\
(0.122)\end{array}$ & $\begin{array}{l}0.704^{* *} \\
(0.116)\end{array}$ & $\begin{array}{c}0.911 \\
(0.154)\end{array}$ & $\begin{array}{c}0.836 \\
(0.144)\end{array}$ & $\begin{array}{c}0.873 \\
(0.155)\end{array}$ & $\begin{array}{c}0.889 \\
(0.159)\end{array}$ & $\begin{array}{c}0.874 \\
(0.157)\end{array}$ & $\begin{array}{c}0.924 \\
(0.168)\end{array}$ & $\begin{array}{c}0.851 \\
(0.157)\end{array}$ \\
\hline 4. BC red & $\begin{array}{l}0.589 * * * \\
(0.101)\end{array}$ & $\begin{array}{l}0.570^{* * *} \\
(0.0991)\end{array}$ & $\begin{array}{l}0.575^{* * *} \\
(0.105)\end{array}$ & $\begin{array}{l}0.582^{* * *} \\
(0.107)\end{array}$ & $\begin{array}{l}0.569 * * * \\
(0.105)\end{array}$ & $\begin{array}{l}0.530^{* * *} \\
(0.0991)\end{array}$ & $\begin{array}{l}0.534^{* * *} \\
(0.100)\end{array}$ & $\begin{array}{l}0.624^{* * *} \\
(0.113)\end{array}$ & $\begin{array}{l}0.590^{* * *} \\
(0.109)\end{array}$ & $\begin{array}{l}0.612^{* *} \\
(0.120)\end{array}$ & $\begin{array}{l}0.614^{* *} \\
(0.121)\end{array}$ & $\begin{array}{l}0.593^{* * *} \\
(0.117)\end{array}$ & $\begin{array}{l}0.556^{* * *} \\
(0.112)\end{array}$ & $\begin{array}{l}0.562^{* * * *} \\
(0.114)\end{array}$ \\
\hline Age & & $\begin{array}{c}0.888 * * \\
(0.0430)\end{array}$ & $\begin{array}{c}0.886 * * \\
(0.0544)\end{array}$ & $\begin{array}{c}0.877^{* *} \\
(0.0544)\end{array}$ & $\begin{array}{c}0.873^{* *} \\
(0.0543)\end{array}$ & $\begin{array}{c}0.858^{* *} \\
(0.0538)\end{array}$ & $\begin{array}{c}0.867 * * \\
(0.0543)\end{array}$ & & $\begin{array}{l}0.820^{* * *} \\
(0.0442)\end{array}$ & $\begin{array}{c}0.825^{* * *} \\
(0.0558)\end{array}$ & $\begin{array}{l}0.821 * * * \\
(0.0558)\end{array}$ & $\begin{array}{l}0.817^{* * *} \\
(0.0556)\end{array}$ & $\begin{array}{l}0.801^{* * *} \\
(0.0552)\end{array}$ & $\begin{array}{l}0.813 * * * \\
(0.0564)\end{array}$ \\
\hline Nationality & & $\begin{array}{c}0.818^{*} \\
(0.0858)\end{array}$ & $\begin{array}{c}0.830 \\
(0.0952)\end{array}$ & $\begin{array}{c}0.842 \\
(0.0969)\end{array}$ & $\begin{array}{c}0.824 * \\
(0.0953)\end{array}$ & $\begin{array}{c}0.830 \\
(0.0970)\end{array}$ & $\begin{array}{c}0.862 \\
(0.101)\end{array}$ & & $\begin{array}{c}0.815^{*} \\
(0.0908)\end{array}$ & $\begin{array}{c}0.802 * \\
(0.0987)\end{array}$ & $\begin{array}{c}0.809 * \\
(0.0999)\end{array}$ & $\begin{array}{c}0.788^{*} \\
(0.0983)\end{array}$ & $\begin{array}{c}0.794^{*} \\
(0.100)\end{array}$ & $\begin{array}{c}0.832 \\
(0.106)\end{array}$ \\
\hline 2. Female & & $\begin{array}{l}0.990 \\
(0.116)\end{array}$ & $\begin{array}{c}0.934 \\
(0.113)\end{array}$ & $\begin{array}{c}0.921 \\
(0.112)\end{array}$ & $\begin{array}{l}0.926 \\
(0.113)\end{array}$ & $\begin{array}{c}0.959 \\
(0.118)\end{array}$ & $\begin{array}{c}0.949 \\
(0.116)\end{array}$ & & $\begin{array}{l}0.997 \\
(0.127)\end{array}$ & $\begin{array}{c}0.957 \\
(0.126)\end{array}$ & $\begin{array}{c}0.949 \\
(0.125)\end{array}$ & $\begin{array}{c}0.954 \\
(0.126)\end{array}$ & $\begin{array}{c}0.992 \\
(0.133)\end{array}$ & $\begin{array}{c}0.975 \\
(0.131)\end{array}$ \\
\hline Education & & $\begin{array}{c}1.130^{*} \\
(0.0801)\end{array}$ & $\begin{array}{c}1.042 \\
(0.0806)\end{array}$ & $\begin{array}{l}1.022 \\
(0.0797)\end{array}$ & $\begin{array}{l}1.039 \\
(0.0816)\end{array}$ & $\begin{array}{l}1.077 \\
(0.0855)\end{array}$ & $\begin{array}{l}1.048 \\
(0.0841)\end{array}$ & & $\begin{array}{l}1.124 \\
(0.0841)\end{array}$ & $\begin{array}{l}1.064 \\
(0.0881)\end{array}$ & $\begin{array}{l}1.049 \\
(0.0875)\end{array}$ & $\begin{array}{c}1.074 \\
(0.0904)\end{array}$ & $\begin{array}{l}1.107 \\
(0.0947)\end{array}$ & $\begin{array}{c}1.077 \\
(0.0930)\end{array}$ \\
\hline Income & & & $\begin{array}{l}1.101^{* * *} \\
(0.0356)\end{array}$ & $\begin{array}{l}1.097 * * * \\
(0.0356)\end{array}$ & $\begin{array}{l}1.099 * * * \\
(0.0358)\end{array}$ & $\begin{array}{l}1.092^{* * *} \\
(0.0357)\end{array}$ & $\begin{array}{r}1.086^{* *} \\
(0.0356)\end{array}$ & & & $\begin{array}{l}1.057 \\
(0.0377)\end{array}$ & $\begin{array}{l}1.056 \\
(0.0379)\end{array}$ & $\begin{array}{l}1.058 \\
(0.0381)\end{array}$ & $\begin{array}{l}1.052 \\
(0.0381)\end{array}$ & $\begin{array}{l}1.043 \\
(0.0381)\end{array}$ \\
\hline Housing tenure & & & $\begin{array}{c}0.991 \\
(0.0848)\end{array}$ & $\begin{array}{l}1.002 \\
(0.0862)\end{array}$ & $\begin{array}{l}1.004 \\
(0.0865)\end{array}$ & $\begin{array}{l}1.050 \\
(0.0915)\end{array}$ & $\begin{array}{l}1.023 \\
(0.0896)\end{array}$ & & & $\begin{array}{l}1.071 \\
(0.0995)\end{array}$ & $\begin{array}{c}1.075 \\
(0.100)\end{array}$ & $\begin{array}{c}1.079 \\
(0.101)\end{array}$ & $\begin{array}{c}1.127 \\
(0.107)\end{array}$ & $\begin{array}{c}1.087 \\
(0.104)\end{array}$ \\
\hline $\mathrm{N}^{\circ}$ years lived & & & $\begin{array}{l}0.999 \\
(0.00437)\end{array}$ & $\begin{array}{l}1.000 \\
(0.00442)\end{array}$ & $\begin{array}{l}0.999 \\
(0.00443)\end{array}$ & $\begin{array}{l}0.995 \\
(0.00453)\end{array}$ & $\begin{array}{l}0.994 \\
(0.00455)\end{array}$ & & & $\begin{array}{l}1.000 \\
(0.00465)\end{array}$ & $\begin{array}{l}1.000 \\
(0.00468)\end{array}$ & $\begin{array}{l}0.999 \\
(0.00470)\end{array}$ & $\begin{array}{l}0.995 \\
(0.00483)\end{array}$ & $\begin{array}{l}0.994 \\
(0.00487)\end{array}$ \\
\hline Protect $\mathrm{UH}^{\mathrm{c}}$ & & & & $\begin{array}{l}1.374 * * * \\
(0.139)\end{array}$ & $\begin{array}{l}1.381 * * * \\
(0.141)\end{array}$ & $\begin{array}{l}1.353^{* * *} \\
(0.139)\end{array}$ & $\begin{array}{l}1.369 * * * \\
(0.139)\end{array}$ & & & & $\begin{array}{l}1.219^{*} \\
(0.126)\end{array}$ & $\begin{array}{l}1.232^{* *} \\
(0.128)\end{array}$ & $\begin{array}{l}1.207^{*} \\
(0.126)\end{array}$ & $\begin{array}{l}1.232 * * \\
(0.129)\end{array}$ \\
\hline Petition ${ }^{d}$ & & & & $\begin{array}{c}0.686^{*} \\
(0.140)\end{array}$ & $\begin{array}{c}0.685^{*} \\
(0.140)\end{array}$ & $\begin{array}{c}0.675^{*} \\
(0.138)\end{array}$ & $\begin{array}{c}0.695^{*} \\
(0.142)\end{array}$ & & & & $\begin{array}{c}0.829 \\
(0.182)\end{array}$ & $\begin{array}{c}0.831 \\
(0.183)\end{array}$ & $\begin{array}{c}0.831 \\
(0.185)\end{array}$ & $\begin{array}{c}0.864 \\
(0.193)\end{array}$ \\
\hline Open space & & & & & $\begin{array}{c}1.115^{* *} \\
(0.0592)\end{array}$ & $\begin{array}{c}1.118^{* *} \\
(0.0594)\end{array}$ & $\begin{array}{c}1.118^{* *} \\
(0.0594)\end{array}$ & & & & & $\begin{array}{c}1.151^{* *} \\
(0.0672)\end{array}$ & $\begin{array}{c}1.150^{* *} \\
(0.0678)\end{array}$ & $\begin{array}{c}1.154^{* *} \\
(0.0685)\end{array}$ \\
\hline NB & & & & & & $\begin{array}{l}1.399 * * * \\
(0.103)\end{array}$ & $\begin{array}{l}1.477^{* * *} \\
(0.114)\end{array}$ & & & & & & $\begin{array}{l}1.377^{* * *} \\
(0.111)\end{array}$ & $\begin{array}{l}1.483^{* * *} \\
(0.125)\end{array}$ \\
\hline Conf. gov. ${ }^{\mathrm{e}}$ & & & & & & & $\begin{array}{l}0.825 * * \\
(0.0631)\end{array}$ & & & & & & & $\begin{array}{l}0.768 * * * \\
(0.0644)\end{array}$ \\
\hline Scenario dummy ${ }^{f}$ & YES & YES & YES & YES & YES & YES & YES & YES & YES & YES & YES & YES & YES & YES \\
\hline Observations & 1,055 & 1,022 & 1,022 & 1,022 & 1,022 & 1,022 & 1,022 & 1,055 & 1,022 & 1,022 & 1,022 & 1,022 & 1,022 & 1,022 \\
\hline $\begin{array}{l}\text { Log likelihood } \\
\text { LR chi2 } \\
\text { Pseudo R2 }\end{array}$ & $\begin{array}{l}-1734 \\
9.89 \\
0.02\end{array}$ & $\begin{array}{c}-1726 \\
25.32 \\
0.07\end{array}$ & $\begin{array}{c}-1455 \\
34.20 \\
0.11\end{array}$ & $\begin{array}{c}-1448 \\
47.49 \\
0.16\end{array}$ & $\begin{array}{c}-1447 \\
50.40 \\
0.17\end{array}$ & $\begin{array}{c}-1437 \\
69.12 \\
0.20\end{array}$ & $\begin{array}{c}-1371 \\
65.26 \\
0.23\end{array}$ & $\begin{array}{l}-727 \\
7.25 \\
0.05\end{array}$ & $\begin{array}{c}-716 \\
29.51 \\
0.20\end{array}$ & $\begin{array}{c}-597 \\
30.11 \\
0.24\end{array}$ & $\begin{array}{c}-595 \\
34.66 \\
0.28\end{array}$ & $\begin{array}{c}-593 \\
38.36 \\
0.31\end{array}$ & $\begin{array}{c}-585 \\
54.27 \\
0.44\end{array}$ & $\begin{array}{c}-553 \\
54.56 \\
0.46\end{array}$ \\
\hline
\end{tabular}

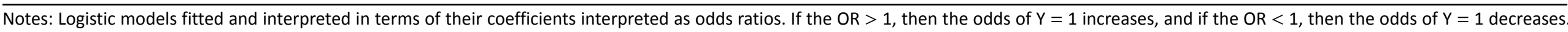

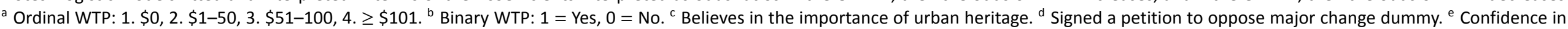
government. ${ }^{f}$ Acceptance of CV scenario. ${ }^{*} p<0.05,{ }^{* *} p<0.01,{ }^{* * *} p<0.001$. 


\section{Conclusions}

The quality of the urban environment in less-developed countries has been increasingly recognised as a key determinant of quality of life (Whittington, 2010). This study sheds light on how morphological densification affects the complex values attached by residents to their urban environments in a quantitively understudied context in the Global South. It also contributes to uncovering some of the darker realities of planning practices (Bou Akar, 2018, p. 5). The intention of this article is to extend recent arguments on the effects of actually existing planning practices (Fawaz, 2017), in this case by examining how living in continual construction, an everyday reality of many deregulated cities in less-developed countries, affects local resident attitudes and values, by exploring specifically how dramatic urban restructuring affects resident values of architectural amenities and NB in Beirut.

Although living in areas with different rates of $B C$ does not affect preferences for architectural amenities, it affects resident socio-political activism towards the preservation of their built environment. NB is not significantly affected by construction rates, but significantly increases both with the number of years lived in a neighbourhood and in locations boasting better building conditions, confirming a role for the built environment with regards to intangible urban amenities. Moreover, despite Lebanese discontent with the Syrian influx in urban areas, higher numbers of Syrian neighbours do not significantly lower the odds of feeling strong NB. This article also finds that approximately $50 \%$ of respondents were willing to pay to stop disruptive building near their location of residence, but residents living in areas with high $\mathrm{BC}$ rates had almost $50 \%$ lower odds of being willing to stop new construction as these areas had already undergone heavy urban transformation.

This article hopes to incite researchers to collect quantitative data in Global South cities. Collecting such data not only allows for a better understanding of resident reactions to urban development processes but can facilitate local urban interventions by exploiting the spatial nature of such data. The consultative nature of such surveys is also a small part of the larger efforts to give residents back their right to the city, as it is often the first step in fostering urban initiatives that give agency to the community and help residents reclaim the city as a co-created space.

\section{Acknowledgments}

This article was financially supported by the Royal Geographical Society (with IGB). The results presented and views expressed are exclusively those of the author. I would like to thank Nancy Holman and Gabriel Ahlfeldt for their guidance throughout the various research stages of this article, and to the participants of the LSE urbanisation, planning and development seminar. I also thank researchers and activists in Beirut who guided me at different stages of the project. Special thanks to the AUB Neighbourhood Initiative for hosting me for the duration of the data collection, and to Mariam Bazzi, Mariam Dandachi, Mikhael Daher, Ghadir Ghamrawi, Aya Itani, Diala Makki, Aline Tashjian, and Yara Younes for their research assistance.

\section{Conflict of Interests}

The author declares no conflict of interests.

\section{References}

Ahlfeldt, G. M., \& Holman, N. (2018). Distinctively different: A new approach to valuing architectural amenities. Economic Journal, 128(608), 1-33.

Alberini, A., \& Kahn, J. R. (Eds.). (2006). Handbook on contingent valuation. Edward Elgar.

Alberini, A., Riganti, P., \& Longo, A. (2003). Can people value the aesthetic and use services of urban sites? Evidence from a survey of Belfast residents. Journal of Cultural Economics, 27(3/4), 193-213.

Ashkar, H. (2011). The role of the state in initiating gentrification: The case of the neighbourhood of Achrafieh [Unpublished master thesis]. Lebanese University.

Ashkar, H. (2018). The role of laws and regulations in shaping gentrification: The view from Beirut. City, 22(3), 341-357.

Bateman, I. J., Carson, R. T., Day, B., Hanemann, M., Hanley, N., Hett, T., Jones-Lee, M., Loomes, G., Mourato, S., Özdemiroglu, E., Pearce, D. W., Sugden, R., \& Swanson, J. (2002). Economic valuation with stated preference techniques: A manual. Edward Elgar.

Bekdache, N. (2015). Evicting sovereignty: Lebanon's housing tenants from citizens to obstacles. The Arab Studies Journal, 23(1), 320-350.

Bou Akar, H. (2018). For the war yet to come: Planning Beirut's frontiers. Stanford University Press.

Brander, L. M., \& Koetse, M. J. (2011). The value of urban open space: Meta-analyses of contingent valuation and hedonic pricing results. Journal of Environmental Management, 92(10), 2763-2773.

Buccianti-Barakat, L., Zouain, G., \& Hariri, N. (2015). Le quartier de Mar Mikhael: Enquête socio-économique [The neighbourhood of Mar Mikhael: A socioeconomic survey]. Travaux et Jours, 89, 1-15.

Calia, P., \& Strazzera, E. (2001). A sample selection model for protest votes in contingent valuation analyses (Working Paper No. 1999.055). Fondazione Eni Enrico Mattei. https://www.feem.it/en/publications/feemworking-papers-note-di-lavoro-series/a-sampleselection-model-for-protest-votes-in-contingentvaluation-analyses

Carson, R., Flores, N., \& Meade, N. (2001). Contingent valuation: Controversies and evidence. Environmental \& Resource Economics, 19(2), 173-210.

Chen, W. Y., \& Hua, J. (2015). Citizens' distrust of government and their protest responses in a contingent val- 
uation study of urban heritage trees in Guangzhou, China. Journal of Environmental Management, 155, 40-48.

Davie, M. F. (2004, November 4-5). Le patrimoine architectural et urbain au Liban: Prise de conscience, idéologies de protection et éléments de prospective [Architectural and urban heritage in Lebanon: Awareness, protection ideologies and elements of foresight] [Paper presentation]. Notre-Dame University, Barsa, Lebanon.

Fawaz, M. (2017). Exceptions and the actually existing practice of planning: Beirut (Lebanon) as case study. Urban Studies, 54(8), 1938-1955.

Fawaz, M., Krijnen, M., \& El Samad, D. (2018). A property framework for understanding gentrification: Ownership patterns and the transformations of Mar Mikhael, Beirut. City, 22(3), 358-374.

Finney, N., \& Jivraj, S. (2013). Ethnic group population change and neighbourhood belonging. Urban Studies, 50(16), 3323-3341.

Gebara, H., Khechen, M., \& Marot, B. (2016). Mapping new constructions in Beirut (2000-2013). Jadaliyya. http://www.jadaliyya.com/Details/33751/MappingNew-Constructions-in-Beirut-2000-2013

Greene, J. C. (2007). Mixed methods in social inquiry. Jossey-Bass.

Harb, M. (2000). Post-war Beirut: Resources, negotiations, and contestations in the Elyssar Project. The Arab World Geographer, 3(4), 272-288.

Jacobs, J. (1961). The death and life of great American cities. Random House.

Johnstone, C., \& Whitehead, M. (Eds.). (2004). New horizons in British urban policy perspectives on New Labour's urban renaissance. Ashgate.

Kaddour, A., Myntti, C., Abdulrahim, S., Salti, N., Wick, L., \& Zurayk, H. (2014). The profile of a neighbourhood: Health and well-being in Ras Beirut. American University of Beirut.

Khechen, M. (2018). The remaking of Ras Beirut. City, 22(3), 375-395.

Krijnen, M. (2018). Beirut and the creation of the rent gap. Urban Geography, 39(7), 1041-1059.

Krijnen, M., \& Fawaz, M. (2010). Exception as the rule: High-end developments in neoliberal Beirut. Built Environment, 36(2), 245-259.

Lewicka, M. (2011). Place attachment: How far have we come in the last 40 years? Journal of Environmental Psychology, 31(3), 207-230.

Lieberman, E. S. (2005). Nested analysis as a mixedmethod strategy for comparative research. American Political Science Review, 99(3), 435-452.

Logan, J. R., \& Molotch, H. L. (2007). Urban fortunes: The political economy of place. University of California Press.

Martin, D. G. (2003). Enacting neighbourhood. Urban
Geography, 24(5), 361-385.

MEDNETA. (2015). Report of the arts, crafts and design sector and urban change in the Beirut district of MarMikhael. http://backend.institutdesfinances.gov.lb/ wp-content/uploads/2020/06/Mediterranean-

cultura-Inetwork-to-promote-creativity-in-the-artscrafts-and-design-for-communities-regenerationin-historical-cities-MEDNETA-.pdf

Neuman, M. (2005). The compact city fallacy. Journal of Planning Education and Research, 25(1), 11-26.

Oh, H., \& Hong, J. H. (2012). Citizens' trust in government and their willingness-to-pay. Economics Letters, 115(3), 345-347.

Pietrostefani, E. (2019a). Essays in planning policy and urban economics [Doctoral dissertation, London School of Economics and Political Science]. LSE Theses Online. http://etheses.Ise.ac.uk/4032

Pietrostefani, E. (2019b, April 1-3). Spatializing displacement: Densification and housing inequality in Beirut [Paper presentation]. City Debates, Beirut, Lebanon.

Provins, A., Pearce, D., Ozdemiroglu, E., Mourato, S., \& Morse-Jones, S. (2008). Valuation of the historic environment: The scope for using economic valuation evidence in the appraisal of heritage-related projects. Progress in Planning, 69(4), 131-175.

Ragette, F. (1980). Architecture in Lebanon: The Lebanese house during the 18th and 19th centuries. Caravan Books.

Roy, A. (2005). Urban informality: Toward an epistemology of planning. Journal of the American Planning Association, 71(2), 147-158.

Rydin, Y. (2013). The future of planning: Beyond growth dependence. Policy Press.

Stamps, A. E., \& Nasar, J. L. (1997). Design review and public preferences: Effects of geographical location, public consensus, sensation seeking and architectural styles. Journal of Environmental Psychology, 17(1), 11-32.

Szabó, Z. (2011). Reducing protest responses by deliberative monetary valuation: Improving the validity of biodiversity valuation. Ecological Economics, 72, 37-44.

Watt, P. (2010). Focus article: Unravelling the narratives and politics of belonging to place. Housing, Theory and Society, 27(2), 115-161.

Whittington, D. (2010). What have we learned from 20 years of stated preference research in lessdeveloped countries? Annual Review of Resource Economics, 2(1), 209-236.

Young, A. F., Russell, A., \& Powers, J. R. (2004). The sense of belonging to a neighbourhood: Can it be measured and is it related to health and well-being in older women? Social Science and Medicine, 59(12), 2627-2637. 


\section{COGITATIO}

\section{About the Author}

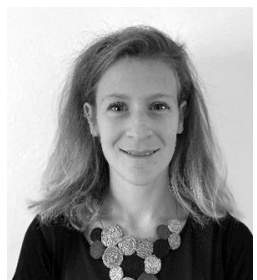

Elisabetta Pietrostefani is an urban geographer and geographic data scientist interested in applying data and technologies to improve the understanding of urban development and inequalities. She holds a $\mathrm{PhD}$ in planning policy and urban economics from the London School of Economics. Her research focuses on the evaluation of urban policies in multiple geographies. She has analysed the effects of density policies and urban development and assessed well-being and inequalities in contexts of mass displacement. 